\title{
Communication
}

[Comunicação]

\section{Nitrogen balance of goat kids fed diets containing peach palm meal}

[Balanço de nitrogênio em caprinos alimentados com dietas contendo farinha de pupunha]

\author{
L.S.O. Ribeiro ${ }^{1}$, M.L.A. Pereira ${ }^{2}$, A.B. Santos $^{1}$, A.J.V. Pires ${ }^{2}$ \\ G.G.P. Carvalho ${ }^{3}$, H.G.O. Silva ${ }^{2}$, T.C.J. Pereira ${ }^{1 *}$
}

\footnotetext{
${ }^{1}$ Aluno de pós-graduação - Universidade Estadual do Sudoeste da Bahia - Itapetinga, BA

${ }^{2}$ Universidade Estadual do Sudoeste da Bahia - Itapetinga, BA

${ }^{3}$ Escola de Medicina Veterinária e Zootecnia - Universidade Federal da Bahia - Salvador, BA
}

The use of agribusiness residues could help to improve the efficiency of livestock production systems by supplying nutrients to animals during periods of feed shortages, reducing costs associated with feeding, and improving the sustainability of the sector by reducing environmental impacts (Santos Filho et al., 2015). Peach palm (Bactris gasipaes Kunth) has become an agricultural species in the humid tropical region of Brazil (Conceição et al., 2018). In addition to providing the heart-of-palm, which has an excellent international market value, its fruit can be used for the extraction of seeds. The heartof-palm industry directs part of the cultivation area to the production of fruit for the extraction of seeds (Pereira et al., 2019a). Hence, this process generates large amounts of fruit pulp waste, which does not yet have a suitable destination.

The pulp is a waste that could be used for the production of peach palm meal (PP) as an alternative feedstuff for ruminants (Santos et al., 2016), but for that, it is necessary to know inclusion levels that guarantee animal productivity. This waste contains oil contents ranging from 20 to $620 \mathrm{~g} \mathrm{~kg}^{-1}$ of DM (Pereira et al., 2019b; Gomez et al., 1998; Murillo et al., 1991, 1983), depending on the amount added to the diet can promote rumen fermentation modification and thus to affect microbial efficiency (Palmquist and Mattos, 2011). In this regard, modifications in the microbial utilization of protein and energy can occur, promoting an increase in urinary urea excretion and negative nitrogen retention.
One of the major challenges in ruminant nutrition is to improve understanding of nitrogen metabolism to formulate the most efficient diets and improve the nutritional management of animals (Silva et al., 2019). Thus, the evaluation of these parameters is necessary to establish limits of applications of sustainable technologies, without causing damage to animal production. This study was conducted to examine the nitrogen balance and the plasma urea concentration in goat kids fed diets containing peach palm meal substituting corn $(0,10,40,60$, and $85 \%$ of the dry matter).

\section{MATERIAL AND METHODS}

All the animal care and handling procedures were approved by the Ethics Committee on Animal Use of the State University of Southwest Bahia UESB, Itapetinga Campus, with protocol number $11 / 2012$. The experiment was conducted in the sheep farming sector of UESB, State of Bahia, Brazil. Thirty Boer crossbred kids, approximately 90 days old and initial body weight of $16.7 \pm$ $3.5 \mathrm{~kg}$, were distributed in a completely randomized design with five treatments $(0,10,40$, 60 , and $85 \%$ peach palm meal (PP) to replace corn in the concentrate) and six replicates. The experimental period was 84 days, with 14 days for adaptation to experimental diets and three 28-day periods for data collection.

The pulp of the pitted fruit (pericarp and mesocarp) was supplied by Indústria de Alimentos no Mercado de Palmitos - 
INACERES, located in Uruçuca municipality, Bahia State, Brazil. The PP was produced in a flour mill at Instituto Federal Baiano IFBAIANO, Uruçuca Campus. The obtained pulp was dried in the sun for three consecutive days, with the material being turned over three times a day until its moisture content was reduced by half. Subsequently, it was disintegrated in a cassava grinder, and then the ground mass was roasted in a mechanized flour roaster. This roasting procedure lasted 30 to $40 \mathrm{~min}$, with the mass being turned over using wooden squeegees until its final drying, at approximately $13 \mathrm{~g} \mathrm{~kg}^{-1}$ moisture.

Diets were isonitrogenous (crude protein at $152 \mathrm{~g}$ $\mathrm{kg}^{-1} \mathrm{DM}$ ) and formulated to allow a body weight (BW) gain rate of $200 \mathrm{~g} \mathrm{day}^{-1}$ as recommended by the NRC (Nutrient..., 2007) for goat kids in the growing. The proximate and chemical compositions of the diets are listed in Table 1. Diets were supplied daily as complete mixing, at $0700 \mathrm{~h}$ and $1600 \mathrm{~h}$, ad libitum, so as to allow for 10 to $20 \mathrm{~g} \mathrm{~kg}^{-1}$ leftover. The daily voluntary intake was calculated as the difference between the total feed supplied and the leftovers, which were collected and weighed in the morning and afternoon, during the 84 experimental days. Similarly, nitrogen $(\mathrm{N})$ intake in $\left(\mathrm{g} \mathrm{day}^{-1}\right)$. The feces were collected at $0600 \mathrm{~h}$ and $1800 \mathrm{~h}$ for five consecutive days in each experimental subperiod. The 24-h feces from each animal were weighed, and $10 \%$ aliquots from each day were sampled, mixed, and stored in a freezer at $-20^{\circ} \mathrm{C}$ for later analyses.

Table 1. Ingredient composition $\left(\mathrm{g} \mathrm{kg}^{-1} \mathrm{DM}\right)$ of the diets, chemical composition of the Tifton 85 hay, peach palm meal (PP) and experimental diets

\begin{tabular}{|c|c|c|c|c|c|c|c|}
\hline \multirow{2}{*}{\multicolumn{3}{|c|}{ Ingredient }} & \multicolumn{5}{|c|}{ Level of substitution (\% DM) } \\
\hline & & & 0 & 10 & 40 & 60 & 85 \\
\hline Tifton 85 hay & & & 300 & 300 & 300 & 300 & 300 \\
\hline Ground corn & & & 507 & 456 & 297 & 203 & 76 \\
\hline Soybean meal & & & 178 & 178 & 178 & 178 & 178 \\
\hline Peach palm meal & & & 0 & 51 & 210 & 304 & 431 \\
\hline Mineral supplement ${ }^{\mathrm{a}}$ & & & 15 & 15 & 15 & 15 & 15 \\
\hline Total & & & 100 & 100 & 100 & 100 & 100 \\
\hline \multicolumn{3}{|l|}{ Chemical composition } & \multicolumn{5}{|c|}{ Experimental diets } \\
\hline & Tifton 85 & $\mathrm{PP}$ & 0 & 10 & 40 & 60 & 85 \\
\hline Dry matter & 928 & 932 & 918 & 927 & 928 & 927 & 929 \\
\hline Organic matter & 916 & 971 & 942 & 938 & 939 & 934 & 933 \\
\hline Ash & 84 & 29 & 58 & 62 & 61 & 66 & 67 \\
\hline Crude protein & 88 & 78 & 154 & 153 & 149 & 146 & 142 \\
\hline NDIP $^{\mathrm{k}}$ & 405 & 116 & 481 & 453 & 450 & 464 & 560 \\
\hline $\mathrm{ADIP}^{\mathrm{c}}$ & 275 & 197 & 251 & 226 & 176 & 192 & 197 \\
\hline Ether extract & 14 & 115 & 24 & 29 & 45 & 51 & 61 \\
\hline Non-fiber carbohydrates & 39 & 658 & 261 & 303 & 319 & 319 & 329 \\
\hline NDFap $^{\mathrm{d}}$ & 737 & 105 & 466 & 417 & 401 & 378 & 375 \\
\hline Acid detergent fiber & 404 & 45 & 236 & 237 & 202 & 217 & 219 \\
\hline Lignin & 20 & 11 & 7 & 6 & 7 & 9 & 11 \\
\hline Total digestible nutrients & 586 & 806 & 727 & 728 & 723 & 722 & 724 \\
\hline $\operatorname{ME}\left(\mathrm{Mcalkg}^{-1}\right)^{\mathrm{e}}$ & -- & 2.30 & 2.80 & 2.80 & 2.80 & 2.80 & 2.80 \\
\hline Total lipids ${ }^{\mathrm{f}}$ & -- & -- & 3.25 & 3.52 & 4.37 & 4.87 & 5.54 \\
\hline Total unsaturated $^{\mathrm{f}}$ & -- & -- & 2.34 & 2.59 & 3.37 & 3.83 & 4.46 \\
\hline
\end{tabular}

a Amount/kg of product: Calcium (max) 240g; Phosphorus 71g; Copper, 400mg; Iron 250mg; Cobalt 30mg; Iodine 40mg; Manganese 1,350mg; Selenium 15mg; Zinc 1,700mg; Fluorine (max) 710mg; Vitamin A 135,000 IU; Vitamin D3 68,000 IU; Vitamin E $450 \mathrm{IU}$; ${ }^{\mathrm{b}}$ Neutral detergent insoluble protein, $\mathrm{g} \mathrm{kg}^{-1} \mathrm{CP}$; ${ }^{\mathrm{c}}$ Acid detergent insoluble protein, $\mathrm{gkg}^{-1} \mathrm{CP} ;{ }^{\mathrm{d}} \mathrm{NDF}$ corrected for ash and protein; ${ }^{\mathrm{e}}$ Metabolizable energy, estimated according to NRC (Nutrient..., 2001); ${ }^{\mathrm{f}} \mathrm{g} 100 \mathrm{~g}^{-1} \mathrm{DM}$.

Samples of feed, leftovers, and feces were predried in a forced-air ventilation oven at $55^{\circ} \mathrm{C}$ for 72 hours and ground through a $1 \mathrm{~mm}$ screen (Wiley mill; A. H. Thomas, Philadelphia, PA).
The contents of dry matter (DM, method INCT CAg - 003/1), mineral matter (MM, method INCT - CA M - 001/1), crude protein (CP, method INCT - CA N - 001/1), and ether extract 
(EE, method INCT-CAg-004/1) contents were determined according to Detmann et al. (2012). For the sequential analyses of neutral (NDF) and acid (ADF) detergent fiber, samples were treated with thermostable alpha-amylase, without sodium sulfate, and corrected for residual ash (Mertens et al., 2002). The NDF correction for nitrogen compounds and estimate of the neutral (NDIN) and acid (ADIN) detergent insoluble nitrogen compounds were carried out according to Licitra et al. (1996). Lignin (method INCT-CA F 005/1) was obtained based on the methodology described by Detmann et al. (2012), with the ADF residue treated with $72 \%$ sulfuric acid. Non-fiber carbohydrates (NFC) content was calculated according to Hall et al. (1999) with modifications, utilizing NDFap. Total digestible nutrients (TDN) were calculated according to Weiss (1999).

The lipid fraction of the experimental diets was determined at the Center for Chromatographic Analyses of UESB, according to the method of Bligh and Dyer (1959). Peak areas were determined by the normalization method using ChromQuest 4.1 software. Peaks were identified by comparison of the retention times of fatty acid methyl esters (Sigma, USA), and after determining the equivalent chain length (Table 1). On the 28th day of each experimental period, after the intermediate weighting session, the urine was collected as spot samples during the animal's spontaneous urination, approximately $4 \mathrm{~h}$ after the morning feeding was supplied.

These samples were intended for the quantification of the urinary concentrations of urea and creatinine, using commercial kits (Bioclin). Blood was collected from the jugular vein approximately $4 \mathrm{~h}$ after the morning feeding, using Vacutainer ${ }^{\circledR}$ tubes containing EDTA. The nitrogen balance (N-retained, $\mathrm{g}$ day $^{-1}$ ) was calculated as follows: $\mathrm{N}$-retained $=\mathrm{N}$ intake $(\mathrm{g})-$ $\mathrm{N}$ in feces $(\mathrm{g})-\mathrm{N}$ in urine $(\mathrm{g})$. The statistical analysis of the data was achieved by the MIXED procedure of the SAS statistical computer program (Statistical..., 2006), considering a mixed model. Polynomial contrasts were performed for the comparison between the means of the diet that contained only corn $(0 \%$ peach palm meal) and the diets in which the corn was substituted for the PP $(10,40,60$, and $85 \%)$. The following statistical model was adopted:

$$
\mathrm{Y}_{i j k}=\left(\beta_{0}+\beta_{1} \mathrm{~T}+\beta_{2} \mathrm{~T}^{2}\right)+\varepsilon_{i j k} ; \mathrm{NID}\left(0 ; \sigma^{2}\right),
$$

where $\mathrm{Y}=$ the estimated value according to the diets; $\beta_{0}=$ intercept; $\beta_{1}$ and $\beta_{2}$ defined the variation of $\mathrm{Y}$ according to the level of substitution; and $\mathrm{T}=$ level of substitution $(0,10$, 40,60 , and $85 \%$ PP). For all statistical procedures, the critical level of probability for type 1 error was fixed at 0.05 .

\section{RESULTS AND DISCUSSION}

The $\mathrm{N}$ intake $\left(\mathrm{g} \mathrm{day}^{-1}\right)$ decreased linearly $(p=$ 0.000) with the elevation in the levels of peach palm meal (PP) in the concentrate (Table 2). The animals fed the diet $0 \%$ (control) ingested $35.11 \%$ more $\mathrm{N}\left(\mathrm{g} \mathrm{day}^{-1}\right)$ than the goat kids fed on the diet with $85 \%$. Similarly, it is possible that the decrease of $\mathrm{N}$ intake caused a reduction in the digested $\mathrm{N}$ (Table 2). According to Van Soest (1994), the rates of excretion of nitrogen compounds in the urine and feces of ruminants are associated with the amount of nitrogen ingested, which may explain the linear reduction ( $p=$ 0.0022 ) in the excretion of $\mathrm{N}$ in the feces (Table 2).

For the urinary $\mathrm{N}$, there was greater excretion for the diet without PP and a linear change $(p=$ 0.0453 ) with an increase of $0.064 \mathrm{~g} \mathrm{day}^{-1}$ to each percentage unit of PP. Consistently, the average $\mathrm{N}$ retention $\left(\mathrm{g} \mathrm{day}^{-1}\right)$ presented a quadratic effect, in which the goat kids presented greater $\mathrm{N}$ utilization $\left(7.0 \mathrm{~g} \mathrm{day}^{-1}\right)$ at a $28.9 \%$ level of replacement. Hence, the corn substitution with PP at this level in the diet may be recommended for better use of $\mathrm{N}$ and upper levels increase the urinary $\mathrm{N}$ excretion as described above. When the protein degradation rate exceeds the carbohydrate fermentation, a large amount of $\mathrm{N}$ compounds can be lost in the urine (Nocek and Russell, 1988; Meijer et al., 1990; Reynolds, 1992).

The diets with PP present an increase in the unsaturated fatty acids content and lignin/NDF ratio, especially in the diets containing $85 \%$ of $\mathrm{PP}$ replacing corn (Table 1), which is related to the negative implication that lipids and bioactive secondary compounds have on ruminal fermentation and feed digestibility by inhibiting microbial growth (Silva et al., 2019; Amira et al., 2014; Martinele et al., 2008; Clement et al., 2004; Nutrient..., 2001). These characteristics of the peach palm meal composition could explain 
reduced energy use in the rumen with increased urinary $\mathrm{N}$ excretion.

The $\mathrm{N}$ retention is a result of the difference between ingested $\mathrm{N}$ and excreted $\mathrm{N}$ through feces and urine (Orlandi et al., 2020; Huntington and Archibeque, 1999), it was observed a linear decrease in $\mathrm{N}$ intake and increase in urinary $\mathrm{N}$ excretion as the PP replaced corn in the concentrated. This reflected in the reduction of $\mathrm{N}$ retention from the levels 28.9, 33.3, and $45.1 \%$, when expressed in day $^{-1}, \%$ ingested $\mathrm{N}$, and $\%$ digested $\mathrm{N}$ respectively (Table 2 ). The results obtained in this study were similar to those observed by Santos et al. (2016) in study with lambs fed the same levels of PP in diets $(0,10,40$, 60 , and $85 \% \mathrm{DM}$ ), which observed a reduction in $\mathrm{N}$ intake and in digested $\mathrm{N}$. The lower retention indicates impaired dietary $\mathrm{N}$ utilization and possibly reduced muscle deposition and low body weight gain since growth animals have a high protein requirement.

Table 2. Nitrogen intake (N-I), nitrogen excreted in feces (N-feces), nitrogen excreted in urine (N-urine), retained nitrogen $(\mathrm{N}-\mathrm{R})$, and digested nitrogen $(\mathrm{N}-\mathrm{D})$ according to levels of substitution of corn by peach palm meal in confined crossbred goat kids

\begin{tabular}{|c|c|c|c|c|c|c|c|c|c|}
\hline \multirow[t]{2}{*}{ Item } & \multicolumn{5}{|c|}{ Level of substitution (\% DM) } & \multirow{2}{*}{ SEM } & \multicolumn{3}{|l|}{$P$ value } \\
\hline & 0 & 10 & 40 & 60 & 85 & & $C^{l}$ & $L$ & $Q$ \\
\hline & \multicolumn{5}{|c|}{$\mathrm{g} \mathrm{day}^{-1}$} & & & & \\
\hline N-I & 18.8 & 18.9 & 14.8 & 15.6 & 12.2 & 0.7 & 0.003 & $0.000^{\mathrm{a}}$ & 0.562 \\
\hline $\mathrm{N}$-feces & 1.1 & 1.1 & 1.0 & 1.0 & 0.8 & 0.1 & 0.186 & $0.002^{\mathrm{b}}$ & 0.077 \\
\hline $\mathrm{N}$-urine & 10.6 & 5.4 & 8.6 & 9.1 & 9.7 & 0.9 & 0.020 & $0.045^{\mathrm{c}}$ & 0.010 \\
\hline $\mathrm{N}-\mathrm{R}$ & 7.1 & 12.4 & 5.2 & 5.7 & 1.7 & 1.4 & 0.349 & 0.000 & $0.001^{\mathrm{d}}$ \\
\hline N-R $(\%$ N-I $)$ & 37.8 & 65.6 & 35.1 & 36.5 & 13.9 & 9.9 & 0.118 & 0.000 & $0.001^{\mathrm{e}}$ \\
\hline N-R (\% N-D) & 40.1 & 69.8 & 37.7 & 37.7 & 14.9 & 10.7 & 0.218 & 0.001 & $0.000^{f}$ \\
\hline N-D & 17.1 & 17.8 & 13.8 & 14.6 & 11.5 & 0.7 & 0.026 & $0.000^{\mathrm{g}}$ & 0.138 \\
\hline N-D $(\%$ N-I $)$ & 94.1 & 94.2 & 93.2 & 93.6 & 94.3 & 0.3 & 0.196 & 0.244 & 0.283 \\
\hline
\end{tabular}

${ }^{1} C$ Contrasts between the diet containing only corn and the diet with levels of substitution of corn by peach palm meal, $L$ linear, $Q$ quadratic; Significant ${ }^{*}(p<0.0001) ;{ }^{* *}(p<0.001) ;{ }^{* * * *}(p<0.01) ;{ }^{* * * *}(p<0.05) ;{ }^{\text {a }} Y=18.7027^{*}-0.0756$ $\mathrm{X}^{*} ;{ }^{b} Y=1.1025^{*}-0.0032 \mathrm{X}^{* *} ;{ }^{\mathrm{c}} Y=5.0182^{*}+0.0638 \mathrm{X}^{*} ;{ }^{\mathrm{d}} Y=5.6069^{*}+0.0974 \mathrm{X}^{* * * *}-0.0017 \mathrm{X}^{2 * * *} ;{ }^{\mathrm{e}} Y=31.1877^{*}+$ $0.6810 \mathrm{X}^{* * *}-0.01040 \mathrm{X}^{2 *} ;{ }^{\mathrm{f}} Y=33.2062^{*}+0.7251 \mathrm{X}^{* *}-0.0111 \mathrm{X}^{2 *} ;{ }^{g} Y=17.0961^{*}-0.0651 \mathrm{X}^{*}$

Also, it can be inferred that, from the replacement level (around 45\%) reported above, the rumen fermentation was modified by PP because of lipid content (Santos et al., 2016). The main mechanisms involved in this process include the physical coating of the fiber, the filling effects on the microbial membranes, and a decrease in the availability of cations by the formation of soaps, which can influence rumen $\mathrm{pH}$, limiting microbial growth, and the toxicity of the excess of polyunsaturated fatty acids to the ruminal microorganisms (Palmiquist and Mattos, 2011). There are several implications of fat for ruminant nutrition, it interferes with rumen fermentation, influences dietary energy utilization, and also affects the intermediate metabolism (Medeiros and Alberitni, 2012).

The concentration of plasma urea- $\mathrm{N}$ showed a quadratic response with maximum concentration $\left(15.6 \mathrm{mg} \mathrm{dL}^{-1}\right)$ at a $38 \%$ replacement by the PP
(Table 3). The excretions of urea and urea-N in the urine $\left(\mathrm{g} \mathrm{day}^{-1}\right)$ were lower at $39 \%$ of corn substitution, when expressed as $\mathrm{mg} \mathrm{kg}^{-1} \mathrm{BW}$, the minimum excretion was observed at a $36 \%$ level. In addition, the group of animals fed diet containing only corn with those that received PP levels showed greater excretion of urea and $\mathrm{N}$ urea in the urine $\left(\mathrm{g} \mathrm{day}^{-1}\right.$ and $\mathrm{mg} \mathrm{kg}^{-1} \mathrm{BW}$ ) (Table 3 ). Lower excretion of urinary $\mathrm{N}$-urea is a consequence of reduced $\mathrm{N}$ intake provided by $\mathrm{PP}$.

According to Van Soest (1994), the amount of excreted $\mathrm{N}$ in urine is related to the $\mathrm{CP}$ content of the diet, whose proportion of $\mathrm{N}$-urea increases when there is an increase in $\mathrm{N}$ intake, since it is associated with a higher production of urea in the liver. In contrast, the low intake of $\mathrm{N}$ presents as a consequence of the reduction of urinary $\mathrm{N}$-urea excretion to maintain the pool of plasma urea, which is under physiological homeostatic control. 
Table 3. Daily excretion of urea, urea nitrogen (N-urea) in the urine and plasma urea nitrogen $(\mathrm{N})$ concentration according to levels of substitution of corn by peach palm meal in confined crossbred goat kids

\begin{tabular}{|c|c|c|c|c|c|c|c|c|c|}
\hline \multirow{2}{*}{ Item } & \multicolumn{5}{|c|}{ Level of substitution (\% DM) } & \multirow{2}{*}{ SEM } & \multicolumn{3}{|c|}{$P$ value $^{I}$} \\
\hline & 0 & 10 & 40 & 60 & 85 & & $\mathrm{C}$ & $L$ & $Q$ \\
\hline & \multicolumn{5}{|c|}{ Concentration in plasma $\left(\mathrm{mg} \mathrm{dL}^{-1}\right)$} & & & & \\
\hline N-urea & 14.2 & 14.8 & 16.4 & 12.5 & 13.4 & 0.3 & 0.864 & 0.055 & $0.037^{\mathrm{a}}$ \\
\hline Urea & 14.2 & \multicolumn{3}{|c|}{ Excretion $\left(\mathrm{g} \mathrm{day}^{-1}\right)$} & 13.7 & 07 & 00001 & 0.339 & $00001^{\mathrm{b}}$ \\
\hline \multirow[t]{2}{*}{ N-urea } & 6.6 & 2.6 & 3.7 & 4.5 & 6.4 & 0.3 & 0.0001 & 0.340 & $0.0001^{\mathrm{c}}$ \\
\hline & \multicolumn{5}{|c|}{ Excretion $\left(\mathrm{mg} \mathrm{kg}^{-1} \mathrm{BW}\right)$} & & & & \\
\hline Urea & 490.2 & 209.6 & 337.0 & 396.6 & 591.3 & 29.1 & 0.022 & 0.004 & $0.0001^{\mathrm{d}}$ \\
\hline $\mathrm{N}$-urea & 228.8 & 97.8 & 157.3 & 185.1 & 275.9 & 13.6 & 0.022 & 0.004 & $0.0001^{\mathrm{e}}$ \\
\hline
\end{tabular}

Ruminants have the ability to change the rates of excretion of $\mathrm{N}$ compounds in urine and feces as a function of the amount of ingested N (Van Soest, 1994). This metabolic characteristic is possibly related to the activity of urea transporters in the kidneys that regulate the rate of urinary excretion and urea transporters in the gastrointestinal tract that regulate the $\mathrm{N}$ excretion in feces (Reynolds and Kristensen, 2008). Although the concentration of plasma $\mathrm{N}$-urea represents only the circulating pool, the renal tubular reabsorption of urea can occur, depending on the requirement for nitrogen by rumen microorganisms.

It may have occurred in this study when the animals consumed diets with an average level of $35 \%$ of PP, whose above levels can impair the microbial activity. Consistently, with increased urea excretion when higher levels of PP were used. The concentration of plasma $\mathrm{N}$-urea varies according to dietary protein/energy ratio, animal species, or category, and studies are needed to establish an optimal range for each situation. A high concentration of $\mathrm{N}$-urea can indicate excess dietary $\mathrm{N}$ and/or an energy metabolic cost from gluconeogenesis and ureagenesis (Stefanello et al., 2018).
Replacing corn with PP reduces the $\mathrm{N}$ intake in goat kids. However, the PP has the potential to replace corn in the concentrated, because maximum $\mathrm{N}$ retention was verified when it replaces corn at $28.9 \%$. Also, from the environmental point of view, the use of the residues of fruit pulp waste (peach palm) contributes to the sustainability of livestock productions, as it supports a reduction of environmental impacts.

\section{ACKNOWLEDGMENTS}

Financial support for this research (Project APP 0049/2011) was provided by the Foundation for Research Support of the State of Bahia (FAPESB). The authors gratefully acknowledge Coordenação de Aperfeiçoamento de Pessoal de Nível Superior (CAPES, Brazil) for the scholarships awarded.

Keywords: agribusiness residues, Bactris gasipaes Kunth, nitrogen excretion, sustainability, urea 


\section{RESUMO}

O objetivo deste estudo foi avaliar o balanço de nitrogênio e a concentração de ureia no plasma em cabritos alimentados com dietas contendo farinha de pupunha em substituição ao milho (0, 10, 40, 60 e $85 \% \mathrm{MS}$ ). Trinta cabritos Boer $\times$ SRD, com 90 dias de idade e peso corporal inicial de 16,7 $\pm 3,5 \mathrm{~kg}$, foram distribuídos em um delineamento inteiramente ao acaso, com seis repetições. As dietas foram fornecidas diariamente ad libitum para permitir 10\% das sobras. Três coletas foram realizadas a cada 28 dias. As dietas foram constituídas por milho, farelo de soja, farinha de pupunha, suplemento mineral e feno de Tifton-85, com a relação volumoso: concentrado de 30:70. O consumo de nitrogênio (N) diminuiu linearmente à medida que a farinha de pupunha substituiu o milho no concentrado. Com relação ao $N$ digerido, os animais alimentados com níveis de farinha de pupunha apresentaram valores inferiores aos alimentados com o milho como única fonte de energia, com médias de 14,9 e 17,1 $\mathrm{g} \mathrm{dia}^{-1}$, respectivamente. A excreção urinária de $N$ diminuiu à medida que a farinha de pupunha substituiu o milho no concentrado. O nível de 39\% de farinha de pupunha reduziu a excreção urinária de ureia. Houve retenção máxima de $\mathrm{N}$ em 7,83g dia-1 para o nível de substituição de milho de $28,9 \%$ em farinha de pupunha.

Palavras-chave: Bactris gasipaes Kunth, excreção de nitrogênio, resíduos do agronegócio, sustentabilidade, ureia

\section{REFERENCES}

AMIRA, C.; LOUISA, G.; LYAS, B. et al. Effects of secondary compounds from cactus and acacias trees on rumen microbial profile changes performed by Real-Time PCR. Int. J. Curr. Adv. Res., v.2, p.660-671, 2014.

BLIGH, E.G.; DYER, W.J. A rapid method of total lipid extraction and purification. Can. J. Biochem. Physiol., v.37, p.911-917, 1959.

CLEMENT, C.R.; WEBER, J.C.; LEEUWEN VAN, J. et al. Why extensive research and development did not promote use of peach palm fruit in Latin America. Agroforestry Syst., v.61, p.195-206, 2004.

CONCEIÇÃO, M.G.; FERREIRA, M.A.; SILVA, J.L et al. Can cactus (Opuntia stricta [Haw. ] Haw) cladodes plus urea replace wheat bran in steers' diet? Asian Australas. J. Anim. Sci., v.31, p.1627-1634, 2018.

DETMANN, E.; SOUZA, M.A.; VALADARES FILHO, S.C. et al. Métodos para análise de alimentos: INCT - Ciência Animal. Viçosa, MG: Suprema, 2012. 214p.

GÓMEZ, G.; VARGAS, R.; QUESADA, S. et al. Crecimiento y conversión alimenticia de ratas Sprague Dawley sometidas a la ingesta de extractos acuosos de pejibaye (Bactrisgasipaes). Agron. Costarricense, v.22, p.185-190, 1998.
HALL, M.B.; HOOVER, W.H.; JENNINGS, J.P. et al. A method for partitioning neutral detergent soluble carbohydrates. J. Sci. Food Agric., v.70, p.2079-2086, 1999.

HUNTINGTON, G.B.; ARCHIBEQUE, S.L. Practical aspects of urea and ammonia metabolism in ruminants. In: AMERICAN SOCIETY OF ANIMAL SCIENCE, 1999, Raleigh. Proceedings... Raleigh: American Society of Animal Science, 1999. p.1-11.

LICITRA, G.; HERNANDEZ, T.M.; VAN SOEST, P.J. Standardization of procedures for nitrogen fractionation of ruminant feed. Anim. Feed Sci. Technol., v.57, p.347-358, 1996.

MARTINELE, I.; EIFERT, E.C.; LANA R.P. et $a l$. Efeito da monensina e do óleo de soja sobre os protozoários ciliados do rúmen e correlação dos protozoários com parâmetros da fermentação ruminal e digestivos. Rev. Bras. Zootec., v.37, p.1129-1136, 2008.

MEDEIROS, S.R.; ALBERTINI, T.Z. Uso de alimentos ricos em lipídeos para a alimentação de bovinos de corte: Recomendações de uso, limitações e impacto na qualidade da carne. In: SIMPÓSIO DE PRODUÇÃO DE GADO DE CORTE, 8., 2012, Viçosa. Anais...Viçosa: Simcorte, 2012.

MEIJER, A.J.; LAMERS, W.H.; CHAMULEAU, R.A. et al. Nitrogen metabolism and ornithine cycle function. Physiol. Rev., v.70, p.701-748, 1990. 
MERTENS, D.R.; ALLEN, M.; CARMANY, J. et al. Gravimetric determination of amylasetreated neutral detergent fiber in feeds with refluxing in beakers or crucibles: collaborative study. J. AOAC Int., v.85, p.1217-1240, 2002.

MURILLO, M.; KRONEBERG, A.; MATA, J.F et al. Estudio preliminar sobre factores inhibidores de enzimas proteolíticas en la harina de pejibaye (Bactrisgasipaes). Rev. Biol. Trop., v.31, p.227-231, 1983.

MURILLO, M.G.; ZUMBADO, M.; COOZ, A.E. et al. Evaluacíon de la harina de pejibaye (Bactrisgasipaes) en dietas para pollas de reemplazo durante el periodo de iniciacíon y engallinas ponedoras al início de postura. Agron. Costarricense, v.15, p.135-141, 1991.

NOCEK, J.E.; RUSSEL, J.B. Protein and energy as an integrated system. Relationship of ruminal protein and carbohydrate availability to microbial synthesis and milk production. J. Dairy Sci., v.71, p.2070-2107, 1988.

NUTRIENT requeriments of dairy cattle. 7.ed. Washington: National Academy Press, 2001.

NUTRIENT requirements of small ruminants: sheep, goats, cervids and new world camelids. Washington: National Academies Press, 2007.

ORLANDI, T.; POZO, C.A.; SCHIAVO, J. et al. Effect of using Acacia mearnsii tannin extract as a feed additive on nutritional variables and productive performance in dairy cows grazing a temperate pasture. Anim. Sci. J., v.91, e13407, 2020.

PALMQUIST, D.L.; MATTOS, W.R.S. Metabolismo de lipídeos na alimentação de ruminantes. In: BERCHIELLI, T.T.; PIRES, A.V.; OLIVEIRA, S.G. (Eds.). Nutrição de ruminantes. Jaboticabal: FUNEP, 2011. cap.10, p.299-322.

PEREIRA, T.C.J.; RIBEIRO, L.S.O.; PEREIRA, M.L.A. et al. Feeding behavior of goat kids fed diets containing peach palm meal. Acta. Sci. Anim. Sci., v.42, e47088, 2019 b.
PEREIRA, T.C.J.; RIBEIRO, L.S.O.; PIRES, A.J.V. et al. Growth performance and apparent digestibility by goats fed diets with peach palm meal replacing maize. Appl. Anim. Sci., v.35, p.563-569, 2019a.

REYNOLDS, C.K. Metabolism of nitrogenous compounds by ruminant liver. J. Nutri., v.122, p.850-854, 1992.

REYNOLDS, C.K.; KRISTENSEN, N.B. Nitrogen recycling through thegut and the nitrogen economy of ruminants: an asynchronous symbiosis. J. Anim. Sci., v.86, p.293-305, 2008.

SANTOS FILHO, H.B.; VÉRAS, R.M.L.; FERREIRA, M.A. et al. Liquid residue of cassava as a replacement for maize in the diets of sheep. Trop. Anim. Health Prod., v.47, p.1083-1088, 2015.

SANTOS, A.B.; PEREIRA, M.L.; SILVA, H.G.O. et al. Nitrogen metabolism in lambs fed diets containing peach palm meal. Trop. Anim. Health Prod., v.48, p.1491-1495, 2016.

SILVA, L.F.P.; DIXON, R.M.; COSTA, D.F.A. Nitrogen recycling and feed efficiency of cattle fed protein-restricted diets. Anim. Prod. Sci., v.59, p.2093-2107, 2019.

STATISTICAL analysis system. User'sguide. Cary: SAS Institute, 2006.

STEFANELLO, S.; MEZZOMO, M.P.; ZENI, D. et al. Oxygen uptake and net flux of metabolites by splanchnic tissues of sheep in response to short-term mesenteric infusion of nitrogenous compounds. J. Anim. Physiol. Anim. Nutr., v.102, p.853-860, 2018.

VAN SOEST, P.J. Nutritional ecology of the ruminant. 2.ed. Ithaca: Cornell University Press, 1994. 476p.

WEISS, W.P. Energy prediction equations for ruminant feeds. In: MAIZEELL NUTRITION CONFERENCE FOR FEED MANUFACTURERS, 61., 1999, Ithaca. Proceedings... Ithaca: Maizeell University, 1999. p.176-185. 